\title{
Insuficiência renal crônica em equino por alteração congênita
}

Danielle Araújo Barbosa', Frederico Fernandes Araújo, Yasmim Varago Farth, Mariana Cosenza, Ana Flavia Costa, Homero Leite

Martins, Pedro Victor Luna Freire Oliveira

Centro Universitário Filadélfia (UniFil), IbiporÃ, PR, Brasil

*Autor correspondente

e-mail: fred_arj@hotmail.com

\section{Resumo}

A insuficiência renal (IR) é uma afecção incomum em equinos e pode ser definida como um decréscimo na taxa de filtração glomerular, resultando em azotemia e em distúrbios eletrolíticos e acido-básicos. A IR pode ser classificada em aguda ou crônica, podendo as causas serem congênitas ou adquiridas. Em animais com menos de 5 anos de idade, a lesão congênita deve ser considerada. Dentre os fatores congênitos que podem levar à uma insuficiência renal crônica destacam-se a agenesia renal, displasia, hipoplasia, rim policístico e hidronefrose. Os fatores adquiridos são aqueles que ocorrem por consequência de danos nos túbulos glomerulares como isquemia renal, componentes nefrotóxicos, infecções do trato urinário, pielonefrites ou obstruções. 0 equino possui grande capacidade de filtração glomerular, e para apresentar sinais clínicos de lesão renal crônica deve apresentar um comprometimento renal de pelo menos dois terços dos rins. Infelizmente, o prognóstico para insuficiência renal crônica por causa congênita é desfavorável, principalmente por ser um fator irreversível. Os animais começam a apresentar perda de peso progressiva e um quadro de azotemia sem mudanças. Normalmente, a indicação acaba sendo a eutanásia, antes que o animal morra por descompensação urêmica ou caquexia. Foi encaminhado ao Hospital Veterinário da Unifil (HV-Unifil), um garanhão da raça Quarto-de-Milha com 2,5 anos de idade, histórico de diminuição de apetite nos últimos 15 dias, perda de peso progressiva e desidratação intensa. Na propriedade havia sido realizada fluidoterapia, onde observou-se que o cavalo urinou após 30 litros de fluído. 0 animal fazia mímica constante para urinar, apresentava curvatura da coluna e respiração ofegante aparentando dor. Ao dar entrada no HV-Unifil, foi solicitado um hemograma completo e exame bioquímico, com os seguintes resultados: ureia 146; creatinina 8,6; cálcio 15,6 ; fósforo 1,4; albumina 1,5; AST 228; GGT 17; e fibrinogênio 400. Na urinálise, as alterações encontradas foram a baixa densidade urinária (isostenúria), no valor de 1,006, e a presença de leucócitos (3/campo). No exame ultrassonográfico foi possível observar 
apenas o rim direito, que apresentava-se de forma geral com tamanho menor, mais hiperecóico. Não havia diferença de região cortical e medular, e verificou-se dilatação de pelve renal e sedimentos hiperecóicos. A bexiga apresentava um leve espessamento de mucosa e áreas hiperecóicas sugestivas de sedimentos. O tratamento realizado foi a hidratação parenteral, passando para enteral após o terceiro dia. Os valores de ureia e creatinina não baixaram em níveis significativos durante o tratamento, chegando a apresentar valores de 616 e 14,7, respectivamente. 0 animal apresentava edema ventral, facial e de prepúcio. Conforme era realizada a hidratação, os edemas aumentavam, a taxa de reposição era diminuída, não sendo possível reestabelecer a hidratação de maneira adequada. Devido a sua piora progressiva, recomendou-se eutanásia. 0 tratamento necessário seria a hemodiálise ou transplante renal, porém devido à inviabilidade de tal tratamento e à falta de resposta ao tratamento clínico, realizou-se a eutanásia. Após a eutanásia, o animal foi submetido à necropsia. Na análise macroscópica dos rins, estes se apresentaram de tamanho pequeno, com inserção ectópica da artéria renal (acima da pelve renal) e multilobulações. À analise histopatológica, evidenciou-se nefrite intersticial crônica associada à necrose tubular. 0 tratamento clínico para insuficiência renal crônica, neste caso, não apresentou a resposta desejada, visto que o animal apresentava uma alteração renal congênita.

Palavras-chave: Anomalia congênita renal. Hipoplasia. Displasia. 